\title{
PENGARUH PENGAWASAN TERHADAP DISIPLIN KERJA GURU PADA SMK "XY" KOTA PEKANBARU
}

\author{
${ }^{1}$ Riska Afriani Dewita ${ }^{2}$ Arhipen Yapentra \\ ${ }^{1}$ Mahasiswi dan ${ }^{2}$ Dosen STIE Riau Pekanbaru \\ Dosen Tetap STIE Riau Pekanbaru \\ Jln. HR Subrantas KM 12 Telp (0761) 63237 Fax (0761) 63366 \\ E-mail : yapentra@lecturer.stieriau-akbar.ac.id
}

\begin{abstract}
This article is the result of co-research the author and students in completing her final education at STIE Riau. The purpose of this research is to study and analyze influence of Supervision toward the Work Discipline of Teachers in the Vocational High School "XY" Pekanbaru. Respondents in this study amounted to 42 teachers and in its presentation the authors describe the descriptive and quantitative methods. Based on the results of data processing using the SPSS application, the t test results in simple linear regression obtained t_count > t_table (8.277> 2.020) and the significance value obtained $0.000<0.05$. In connection with positive and significant supervision of the Work Discipline, Teachers with a contribution of 45.6\%, based on the R Square Value obtained by 0.456 or $45.6 \%$.
\end{abstract}

Keywords: Supervision, Work Discipline

\section{Pendahuluan}

Pendidikan adalah suatu proses yang mempunyai peranan sangat penting dalam mencerdaskan kehidupan bangsa sebagaimana diamanahkan oleh Undang-undang Dasar 1945, dan sekolah merupakan salah satu lembaga yang mempunyai tugas adalah melaksanakan pendidikan dalam rangka meningkatkan Sumber Daya Manusia (SDM) dan mencerdaskan rakyat Indonesia pada umumnya. Hal ini disebabkan Sumber Daya Manusia merupakan modal utama bagi suatu Negara agar mampu sejajar dengan Negara tetangga. Mengingat begitu pentingnya peran siswa dalam dalam menentukan mutu pendidikan, maka guru dituntut hendaknya benar-benar memahami kepribadian, potensi dan keadaan siswanya dengan sebaik-baiknya. Dengan memahami potensi mereka serta kondisi yang tampak pada siswa, guru akan memberikan pelayanan atau pendidikan yang terbaik kepada anak didiknya dengan segala kendala dan tantangan perkembangan zaman yang sangat berpengaruh dalam pembentukan akhlak anak.

Peranan guru adalah hal yang sangat penting dalam meningkatkan mutu pendidikan dan kemampuan siswa. Mutu pendidikan Indonesia harus terus ditingkatkan sejalan dengan perkembangan era globalisasi. Hasil studi PISA (Program for International Student Assessment) pada tahun 2011,yaitu studi yang memfokuskan pada literasi bacaan, matematika, dan IPA,menunjukkan peringkat Indonesia baru bisa menduduki 10 besar terbawah dari 65 negara, sedangkan pada tahun 2015 Indonesia berada pada urutan 69 dari 75 negara di dunia (Muhali, 2018)

Seorang guru wajib mempunyai pengetahuan dan skill (keterampilan) mengajar yang memadai agar siswa dapat mencerna ilmu yang diberikan dengan baik dan maksimal. Setiap guru selayaknya bisa memberikan contoh baik kepada peserta didiknya, termasuk diantarnya adalah pola hidup disiplin dalam berbuat dan bekerja, dalam perkataan dan perbuatan (Kristi Wardani, 2010)

Dengan demikian maka disiplin Kerja guru merupakan hal yang harus sangat diperatikan dan dijaga oleh setiap pribadi terutama oleh pimpinan yang mempunyai kewenangan untuk melakukan evaluasi dan pengawasan kepada semua anggota atau karyawannnya. 
Disiplin Kerja guru merupakan hasil yang dicapai oleh guru dalam melaksanakan tugastugas yang dibebankan kepadanya yang didasarkan atas kecakapan, pengalaman dan kesungguhan serta penggunaan waktu.

SMK "XY” Pekanbaru adalah salah satu sekolah di bawah organisasi keislaman yang ada sekitar Panam Kota Pekanbaru dengan jumlah guru setiap tahunnya tersu bertambah seiring dengan semakin bertambah siswa baru di lingkungan SMK "XY” Pekanbaru.Jumlah guru yang ada saat ini adalah sebagai mana table berikut :

Tabel 1 Data Jumlah Guru SMK "XY" Pekanbaru Tahun Pelajaran 2013/2014 2017/2018

\begin{tabular}{|c|c|c|c|c|}
\hline \multirow{2}{*}{$\begin{array}{c}\text { Tahun } \\
\text { Pelajaran }\end{array}$} & \multirow{2}{*}{$\begin{array}{c}\text { Guru } \\
\text { Tetap } \\
\text { Yayasan }\end{array}$} & \multicolumn{2}{|c|}{ Guru Tidak Tetap } & \multirow{2}{*}{$\begin{array}{c}\text { Jumlah } \\
\text { Guru }\end{array}$} \\
\cline { 3 - 4 } & & $\begin{array}{c}\text { Guru } \\
\text { Kontrak }\end{array}$ & $\begin{array}{c}\text { Guru } \\
\text { Honor }\end{array}$ & \\
\hline $2013 / 2014$ & 2 & 5 & 20 & 27 \\
$2014 / 2015$ & 2 & 5 & 17 & 24 \\
$2015 / 2016$ & 2 & 5 & 18 & 25 \\
$2016 / 2017$ & 2 & 5 & 25 & 32 \\
$2017 / 2018$ & 14 & 15 & 14 & 43 \\
\hline
\end{tabular}

Sumber : SMK “XY” Pekanbaru 2018

Dari tabel di atas terlihat bahwa jumlah guru di SMK "XY" cenderung bertambah seiring dengan pertambahan jumlah siswa setiap tahun tahun ajaran. Selanjutnya untuk melaksanakan proses pembelajaran yang sesuai dengan target dan tujuan yang akan dicapai, tentunya setiap guru harus membuat Rencana Pelaksanaan Pembelajaran (RPP) untuk setiap semesternya dan diserahkan kepada kepala sekolah di setiap awal semester atau sesuai ketentuan yang telah ditetapkan sekolah.

Adapun data jumlah guru yang menyerahkan RPP di sekolah "XY" adalah sebagaimana tabel berikut :

Tabel 2 Data Guru Yang Menyerahkan RPP

Pada SMK "XY" T.P. 2013/2014 s/d 2017/2018

\begin{tabular}{|c|c|c|c|c|c|}
\hline $\begin{array}{c}\text { Tahun } \\
\text { Pelajaran }\end{array}$ & $\begin{array}{c}\text { Jml } \\
\text { Guru }\end{array}$ & $\begin{array}{c}\text { Tepat } \\
\text { waktu }\end{array}$ & $(\%)$ & $\begin{array}{c}\text { Tidak } \\
\text { Tepat } \\
\text { waktu }\end{array}$ & $(\%)$ \\
\hline $2013 / 2014$ & 27 & 14 & 51,85 & 10 & 48,15 \\
$2014 / 2015$ & 24 & 18 & 75,00 & 17 & 25,00 \\
$2015 / 2016$ & 25 & 21 & 84,00 & 11 & 16,00 \\
$2016 / 2017$ & 32 & 19 & 59,38 & 15 & 40,63 \\
$2017 / 2018$ & 43 & 25 & 58,14 & 18 & 41,86 \\
\hline
\end{tabular}

Sumber : SMK “XY” Pekanbaru 2018

Eko dan Bisnis (Riau Economics and Business Reviewe) Volume 10, Nomor 3, 27 September 2019
Dari tabel di atas dapat dilihat bahwa setiap tahunnya ada lebih dari $40 \%$ guru yang ada menyerahkan RPP tidak tepat pada waktu yang telah ditentukan, bahkan ada sebagian diantarnya yang menyerahkan RPP setelah proses pembelajaran berjalan hingga dua bulan atau lebih, Sementara guru yang menyerahkan RPP tepat waktu yang ditentukan tidak mencapai $60 \%$ dari seluruh guru yang ada di SMK "XY"

Kondisi ini tentunya secara eksplisit menggambarkan sikap kurang disiplinnya para guru yang ada di SMK "XY". Hal lain yang terlihat oleh Penulis saat melakukan observasi ke SMK "XY" tentang kedisiplin-an ini adalah, masih terus meningkatnya pelanggaran atas peraturan ketentuan kehadiran kerja para guru yang dibuktikan dengan hasil rekap absensi (finger print) sebagaimana pada tabel 3 berikut;

Tabel 3 Data Absensi Guru SMK "XY" Pekanbaru Tahun Pelajaran 2013/2014 s/d 2017/2018

\begin{tabular}{|c|c|c|c|c|c|c|c|}
\hline $\begin{array}{c}\text { Tahun } \\
\text { Ajaran }\end{array}$ & $\begin{array}{c}\text { Jml } \\
\text { Guru }\end{array}$ & $\begin{array}{c}\text { Jumlah } \\
\text { HKE }\end{array}$ & $\begin{array}{c}\text { Jml } \\
\text { HKE } * \\
\text { Jml } \\
\text { Guru }\end{array}$ & $\begin{array}{c}\text { Alpha } \\
\text { (Hari) }\end{array}$ & $\begin{array}{c}\text { DL } \\
\text { dan } \\
\text { PC } \\
\text { (Hari) }\end{array}$ & Jml & $\%$ \\
\hline $2013 / 2014$ & 27 & 220 & 5940 & 7 & 31 & 38 & 0,64 \\
\hline $2014 / 2015$ & 24 & 222 & 5328 & 4 & 37 & 41 & 0,77 \\
\hline $2015 / 2016$ & 25 & 228 & 5700 & 6 & 34 & 40 & 0,70 \\
\hline $2016 / 2017$ & 32 & 232 & 7424 & 8 & 46 & 54 & 0,73 \\
\hline $2017 / 2018$ & 43 & 230 & 9890 & 14 & 59 & 73 & 0,74 \\
\hline
\end{tabular}

Sumber: SMK “XY” Pekanbaru 2018

Keterangan $\quad:$ HKE $=$ Hari Kerja Efektif

$\mathrm{DL}=$ Datang terLambat $\mathrm{PC}=$ Pulang Cepat

Dari tabel 3 di atas dapat dilihat bahwa ada kecenderungan peningkatan pelanggaran ketentuan kehadiran guru di sekolah, terutama pada tiga tahun terakhir.

Setiap peraturan dibuat organisasi tentu dengan harapan dipatuhi semua bagian dari organisasi tersebut, maka biasanya aturan dibuat disertai dengan sanksi bagi siapa saja melanggar aturan tersebut (Mangkunegara, 2011). Selanjutnya aturan dan sanksi harus dijalankan secara tegas dan adil dalam setiap organisasi ataupun perusahaan (Yapentra, 2018) .

Berikut data sanksi yang pernah diberikan kepada para guru di SMK "XY" Pekanbaru 
terkait terjadi pelanggaran atau sikap indisipliner

Tabel 4 Data Jumlah Sanksi yang diberikan kepada Guru Sesuai dengan Bentuk Pelanggaran TA. 2013/2014 s/d 2017/2018

\begin{tabular}{|c|c|c|c|c|c|c|}
\hline \multirow{2}{*}{ No } & \multirow{2}{*}{ Bentuk Sanksi } & \multicolumn{5}{|c|}{$\begin{array}{c}\text { Jumlah Sanksi Yang } \\
\text { berikan } \\
\text { (Tahun Pelajaran) }\end{array}$} \\
\hline & & $\begin{array}{r}13 / \\
14\end{array}$ & $\begin{array}{r}14 / \\
15\end{array}$ & $\begin{array}{r}15 / \\
16\end{array}$ & $\begin{array}{r}16 / \\
17\end{array}$ & $\begin{array}{r}17 / \\
18\end{array}$ \\
\hline \multirow{4}{*}{1} & \multirow{4}{*}{$\begin{array}{l}\text { Sanksi Ringan (Teguran Lisan) } \\
\text { a. Datang tidak tepat waktu } \\
\text { b. Izin tanpa keterangan } \\
\text { c. Tidak membuat RPP sesuai } \\
\text { prosedur }\end{array}$} & & & & & \\
\hline & & 10 & 8 & 9 & 9 & 10 \\
\hline & & 3 & 2 & 2 & 3 & 5 \\
\hline & & 5 & 7 & 8 & 9 & 10 \\
\hline \multirow{3}{*}{2} & \multirow{3}{*}{$\begin{array}{l}\text { Sanksi Sedang (Surat } \\
\text { Peringatan I) } \\
\text { a. Izin 3x berturut-turut tanpa } \\
\text { keterangan } \\
\text { b. Melanggar peraturan yang } \\
\text { diberikan oleh pihak } \\
\text { sekolah }\end{array}$} & & & & & \\
\hline & & 2 & 2 & 2 & 1 & 2 \\
\hline & & 0 & 1 & 0 & 1 & 1 \\
\hline \multirow{4}{*}{3} & $\begin{array}{l}\text { Sanksi Berat (Surat Peringatan } \\
\text { III) }\end{array}$ & & & & & \\
\hline & \multirow{2}{*}{$\begin{array}{l}\text { a. Berbuat asusila } \\
\text { b. Berbuat kriminal } \\
\text { (mencuri/berkelahi) }\end{array}$} & 0 & 0 & 0 & 0 & 0 \\
\hline & & 0 & 0 & 0 & 0 & 0 \\
\hline & $\begin{array}{l}\text { c. Korupsi/penggelapan uang } \\
\text { institusi }\end{array}$ & 0 & 0 & 0 & 1 & 0 \\
\hline & Total & 20 & 20 & 21 & 24 & 24 \\
\hline
\end{tabular}

Sumber : SMK “XY” Pekanbaru 2018

Dari table di atas terlihat bahwa ada kecenderungan peningkatan sanksi yang diberikan pimpinan kepada para guru di SMK "XY" Pekanbaru namun demikian ada sebagian guru yang mengatakan bahwa sesungguhnya pelanggaran yang terjadi jauh lebih banyak lagi yang mendapatkan sanksi, setidakya pada sanksi ringan. Maka di sini sangat diperlukan ke arifan dan ketegasan pimpinan dalam melakukan pengawasan dan memberikan sanksi dari setiap pelanggaran secara adil. Steyn dalam Titin Eka Ardiana (2018) menyebutkan seorang pemimpin kepala sekolah yang efektif akan mampu membentuk etos kerja guru yang baik, termotivasi untuk bekerja secara efektif.

Adapun bentuk pengawasan (internal) yang dilakukan pimpinan di lingkungan SMK "XY" adalah sebagai berikut :

Eko dan Bisnis (Riau Economics and Business Reviewe) Volume 10, Nomor 3, 27 September 2019
Tabel 5 Bentuk Kegiatan Pengawasan yang dilakukan di SMK "XY" Pekanbaru

\begin{tabular}{|l|l|}
\hline \multicolumn{1}{|c|}{ Bentuk Pengawasan } & \multicolumn{1}{|c|}{ Volume } \\
\hline Absensi Finger Print & $\begin{array}{l}\text { 2 per hari (Setiap masuk dan } \\
\text { pulang kerja) }\end{array}$ \\
\hline Upacara Bendera & $1 \times$ seminggu (Setiap Hari Senin) \\
\hline Rapat Dinas (bulanan) & $\begin{array}{l}1 \times \text { xebulan (setiap hari Sabtu } \\
\text { minggu I) }\end{array}$ \\
\hline Rapat Dinas (Semester) & $2 \times$ per- enam bulan \\
\hline
\end{tabular}

Sumber : SMK “XY” Pekanbaru 2018

Dari tabel di atas dapat dilihat bahwa setidaknya ada empat bentuk pengawasan internal yang dilakukan kepala sekolah yang bisa dimonitor, dilakukan evaluasi baik harian, bulanan maupun per-semester dan tahun ajaran. Sehingga yang perlu diperhatikan sejauh apakah hasil pengawasa tersebut di tindaklanjuti oleh pimpinan.

Beranjak dari latar belakang fenomena di atas maka Penulis melakukan penelitian bersama dengan mahasiswa dalam penyelesaian studi program Studi S.1 Manajemen dengan judul Penelitian : Pengaruh Pengawasan Terhadap Disiplin Guru pada SMK "XY" Pekanbaru.

\section{Tujuan dan Manfaat Penelitian}

\section{Tujuan Penelitian}

Tujuan penelitian ini adalah untuk mengetahui pengaruh Pengawasan terhadap Disiplin Kerja guru pada SMK "XY" Pekanbaru.

\section{Manfaat Penelitian}

Adapun manfaat penelitian ini adalah:

a. Bagi penulis

Penelitian ini sangat berguna untuk menambah wawasan dalam memahami pentingnya pengaruh Pengawasan terhadap Disiplin Kerja guru dan sebagai landasan berpijak untuk penelitian lanjutan dengan ruang lingkup yang lebih luas.

b. Bagi sekolah

Diharapkan penelitian ini akan memberikan masukan untuk dapat lebih meningkatkan Disiplin Kerja guru pada SMK "XY” Pekanbaru.

P.ISSN: 1410-7988 E.ISSN: 2614-123X 
c. Bagi pihak lain

Diharapkan dapat memberikan informasi dan referensi bagi pihak lain yang membutuhkan terutama untuk penelitian selanjutnya.

\section{B. Tinjauan Pustaka}

Penelitian yang relevan dengan kajian ini sudah ada beberapa penelitian sebelum-nya, diantaranya adalah :

Nellitawati, 2012 dengan judul penelitian (skripsi) Kontribusi Pengawasan Kepala Sekolah Terhadap Disiplin Kerja Guru SMA Negeri Di Kecamatan Koto Tangah Padang. Hasil pengolahan data kajian menunjukkan bahwa $39,40 \%$ pelaksanaan pengawasan oleh kepala sekolah memiliki skor di atas kelas interval rata-rata, dan $42,42 \%$ yang mempunyai skor di bawah kelas interval rata-rata. Tingkat capaian responden termasuk kategori baik dengan skor $83,96 \%$ dari skor ideal. Selanjutnya $46,97 \%$ disiplin kerja guru memiliki skor di atas kelas interval rata-rata, dan $25,76 \%$ yang mempunyai skor di bawah kelas interval ratarata. Tingkat capaian responden termasuk kategori baik dengan skor $86,91 \%$ dari skor ideal. Besarnya nilai koefisien korelasi $r_{x y}=$ 0,722 dengan $=0,001<0,01$. Ini berarti bahwa terdapat hubungan yang signifikan antara pengawasan kepala sekolah dengan disiplin kerja guru, dan besarnya koefisien determinasi $\left(\mathrm{R}^{2}\right)$ sebesar 0,522. Dengan demikian hipotesis yang menyatakan bahwa "pengawasan Kepala Sekolah berkontribusi terhadap disiplin kerja guru dapat diterima dalam taraf kepercayaan 99\% dan besarnya kontribusi 52,2\%

Eva Dila Fitrianingrum, 2015, Pengaruh Pengawasan Terhadap Disiplin Kerja Pada kantor Kecamatan Samarinda Ulu Kota Samarinda. Dari hasil uji hipotesis menjelaskan bahwa $\mathrm{H}_{\mathrm{a}}$ diterima yaitu dan Ho ditolak. Hal ini dibuktikan dengan nilai $\mathrm{r}$ hitung $>\mathrm{r}$ tabel $(0,539>0,381)$ yang termasuk dalam kategori sedang. Selanjutnya besar nilai pengaruh antara pengawasan terhadap disiplin kerja pegawai di lihat dari nilai koefisien yang diperoleh, yaitu sebesar 0,68 yang menunjukkan bahwa jika pengawasan diperhatikan atau terjadi peningkatan pengawasan maka disiplin kerja pegawai akan mengalami perubahan atau peningkatan nilai sebesar 0,68 atau $68 \%$. Dengan demikian hasil analisis menunjukkan bahwa variabel pengawasan mempunyai pengaruh terhadap variabel disiplin kerja pegawai sebesar $68 \%$.

Febriana Louise Purba (2011) judul Penelitian (Skripsi) : Pengaruh Pengawasan Terhadap Disiplin Kerja Karyawan Pada PT. Bank Perkreditan Rakyat Pijer Podi Kekelengen Desa Sukamakmur Kecamatan Sibolangit. Berdasarkan Koefisien Korelasi product Moment yaitu sebesar 0,54. Dengan demikian dapat dikatakan bahwa terdapat hubungan yang positif antara pengawasan terhadap disiplin kerja karyawan pada PT. Bank Perkreditan Rakyat Pijer Podi Kekelengen Desa Sukamakmur kecamatan Sibolangit. Adapun dari hasil perhitungan kefisien determinan diperoleh bahwa besarnya pengaruh pengawasan terhadap disiplin kerja pegawai pada PT. Bank Perkreditan Rakyat Pijer Podi Kekelengen Desa Sukamakmur kecamatan Sibolangit adalah sebesar 29,16\%, dan 70,84 \% selebihnya dipengaruhi oleh faktor lain yang belum diperhitungkan dalam penelitian ini.

Pengawasan secara umum dapat didefenisikan sebagai cara suatu organisasi mewujudkan kinerja yang efektif dan efisien, serta lebih jauh mendukung terwujudnya visi dan misi organisasi. Menurut Said Achmad Kabiru Rafiie (2017), pengawasan merupakan fungsi manajemen yang berkaitan dengan proses dilaksanakan secara teratur untuk memastikan perencanaan, pengorganisasian, kepemimpinan mampu mencapai target, sasaran dan tujuan yang telah ditetapkan organisasi.

\section{Pengawasan}

Pengawasan adalah sebagai upaya yang sistematik untuk mengamati dan memantau apakah berbagai fungsi, akativitas, dan kegiatan yang terjadi dalam organisasi sesuai dengan rencana yang telah ditetapkan sebelumnya atau tidak, (Siagiaan, 2010).Menurut Brantas dalam Irham Fahmi (2013), pengawasan adalah sebuah proses 
pemantauan, penilaian dan pelaporan rencanan atau pencapaian tujuan yang telah ditetapkan untuk tindakan korektif guna penyempurnaan lebih lanjut.

Menurut Winardi dalam Kadarisman (2014) mengemukakan bahwa fungsi pengawasan adalah :

1) Menetapkan tujuan-tujuan dan merencanakan bagaimana mencapainya.

2) Menentukan berapa banyak orang (karyawan) diperlukan seta keterampilanketerampilan yang perlu dimiliki mereka (organization).

3) Menyeleksi individu-individu untuk mengisi posisi (staffing) dan kemudian mereka diberi tugas kerja dan dia membantu mereka bertanggung jawab untuk melaksanakannya dengan baik (direction).

4) Dengan aneka macam laporan, ia meneliti bagaimana baiknya rencana-rencana dilaksanakan dan ia mempelajari kembali rencana-rencana sehubungan dengan hasilhasil yang dicapai dan apabila perlu, rencana-rencana tersebut di modifikasi.

Tujuan pengawasan menurut Husnaini (2001), adalah sebagai berikut :

1) Menghentikan atau meniadakan kesalahan, penyimpangan, penyelewengan, pemborosan dan hambatan.

2) Mencegah terulang kembalinya kesalahan, penyimpangan, pemborosan dan hambatan.

3) Meningkatkan kelancaran operasional organisasi

4) Melakukan tindakan koreksi terhadap kesalahan yang dilakukan dalam pencapaian kerja yang baik

Adapun beberapa faktor yang mempengaruhi pengawasan menurut Mulyadi (2016) adalah :

1) Perubahan yang selalu terjadi baik baik dari luar maupun dari dalam organisasi.

2) Kompleksitas organisasi memerlu-kan pengawasan formal karena adanya disentralisasi kekuasaan.

3) Kesalahan atau penyimpangan yang dilakukan anggota organisasi memerlukan pengawasan

Eko dan Bisnis (Riau Economics and Business Reviewe) Volume 10, Nomor 3, 27 September 2019
Selanjutnya untuk memudahkan dalam merumuskan kuisiner dalam penelitian ini, maka Penulis menggunakan indikator Pengawasan sebagaimana yang disebutkan oleh Handoko (2012), yaitu : 1) akurat, 2) tepat waktu, 3) Obyektif dan menyeluruh 4) Terpusat pada titik - titik pengawasan strategi, 5) Realistik secara ekonomi, 6) Realistik secara organisasional, 7) Terkoordinasi dengan aliran kerja organisasi, 8) Fleksibel, 9) Bersifat sebagai petunjuk dan operasional, 10) Diterima para anggota organisasi.

\section{Disiplin Kerja}

Disiplin merupakan kesadaran dan kesetiaan seseorang menaati semua peraturan perusahaan atau organisasi dan norma-norma sosia yang berlaku, dimana pegawai selalu datang dan pulang tepat waktu serta mengerjakan semua pekerjaan dengan baik (Hasibuan, 2017)

Siagiaan (2010), menyebutkan bahwa terdapat dua jenis disiplin yaitu :

1) Disiplin pervektif

Adalah tindakan yang mendorong para karyawan untuk taat kepada berbagai ketentuan yang berlaku dan memenuhi standar yang telah ditetapkan.

2) Disiplin korektif

Adalah tindakan yang jika ada karyawan yang nyata-nyata telah melakukan pelanggaran atas yang berlaku atau gagal memenuhi standar yang telah ditetapkan, kepadanya dikenakan sanksi disipliner

Adapun faktor-faktor yang mempengaruhi disiplin pegawai menurut Singodimedjo dalam Edy Sutrisno (2017) adalah : 1) Besar kecilnya pemberian kompensasi, 2) Ada tidaknya teladan pemimpin dalam organisasi, 3) Ada tidaknya aturan pasti yang dapat dijadikan pegangan, 4) Keberanian pemimpin dalam mengambil tindakan, 5) Ada tidaknya pengawasan pimpinan, 6) Ada tidaknya perhatian kepada bawahan, 7) Diciptakan kebiasaan-kebiasaan yang mendukung tegaknya disiplin.

Gejala yang bisa menjadi indikator disiplin antara lain seperti disebutkan oleh Veithzal Rivai dalam Sinambela (2016), 
yakni : 1) Kehadiran, 2) Ketaatan pada peraturan kerja, 3) Ketaatan pada standar kerja, 4) Tingkat kewaspadaan tinggi, dan 5) Bekerja etis.

Menurut Henry Simamora dalam Mangkunegara, (2011) menyatakan bahwa terdapat hubungan antara Pengawasan terhadap Disiplin Kerja. Faktor yang mempengaruhi Disiplin Kerja diantaranya adalah Pengawasan. Berdasarkan tiori tersebut maka Penulis membuat hipotesis Diduga Pengawasan Berpengaruh positif dan signifikan terhadap disiplin kerja guru pada SMK "XY" Pekanbaru.

\section{Metodelogi}

Responden yang menjadi Sampel dalam penelitian ini menggunakan sampel jenuh (Sugiyono, 2014), yartinya seluruh populasi menjadi sampel, yaitu sebanyak 43 orang guru dikurang satu orang Kepala Sekolah, sebagai subyek yang melakukan pengawasan, sehingga total Responden (Sampel) Penelitian ini adalah $43-1=42$ orang.

Teknik pengumpulan data melalui observasi dan kuisioner menggunakan skala Likert dengan rentang skor 1 hingga 5. Adapun metode analisa data secara Kuantitatif menggunakan Regresi Linier sederhana dengan bantuan aplikasi SPSS.

Adapun untuk instrumen penelitian dilakukan uji instrumen berupa ; Uji Validitas, Uji Reliabilitas dan Uji Normalitas. Selanjutnya untuk menguji hipotesis dilakukan dengan Uji T dan Uji Koefisien Diteriminasi $\left(\mathrm{R}^{2}\right)$, semua uji tersebut dengan tingkat signifikansi $95 \%$ atau ambang ke-alpaan 0,05.

\section{Hasil dan Pembahasan}

Hasil Uji Instrumen yang dilakukan menghasilkan bahwa semua pernyataan dalam kuisioner dinyatakan valid, reliabel dan terdistribusi secara normal berdasarkan hasil uji yang diperoleh semua pernyataan variabel melampaui batas nilai kritis (minimum) untuk setiap jenis pengujian.

Berdasarkan hasil kuantiatif jawaban dari 42 Responden, yang dilakukan pengujian regresi dengan aplikasi SPSS diperoleh nilai konstanta

Eko dan Bisnis (Riau Economics and Business Reviewe) Volume 10, Nomor 3, 27 September 2019 dan koefisien variabel Pengawasan sebagaimana tabel 6 dibawah ini :

Tabel 6 Hasil Pengujian Regresi Linear Sederhana

\begin{tabular}{|c|c|c|c|c|c|}
\hline \multirow[b]{2}{*}{ Model } & \multicolumn{2}{|c|}{$\begin{array}{l}\text { Unstandardized } \\
\text { Coefficients }\end{array}$} & \multirow{2}{*}{$\begin{array}{c}\begin{array}{c}\text { Standardized } \\
\text { Coefficients }\end{array} \\
\text { Beta } \\
\end{array}$} & \multirow[b]{2}{*}{$\mathrm{t}$} & \multirow[b]{2}{*}{ Sig. } \\
\hline & B & Std. Error & & & \\
\hline $1 \quad$ (Constant) & 4.545 & 5.013 & & .907 & .370 \\
\hline Pengawasan & .371 & .064 & .675 & 5.790 & .000 \\
\hline
\end{tabular}

Guru

Hasil pengolahan data menggunakan aplikasi SPSS, didapat nilai $\mathrm{a}=4.545$ dan $\beta$ $=0,371$ dengan persamaan regresi linear sederhana adalah : $\mathrm{Y}=\mathrm{a}+\beta \mathrm{X}$, maka setelah di masukkan ke dalam persamaan regresi linear sederhana diperoleh hasil sebagai berikut :

$$
\begin{aligned}
& Y=a+\beta X \\
& Y=\mathbf{4 , 5 4 5 + 0 , 3 7 1}
\end{aligned}
$$

Keterangan :

$\mathrm{Y}=$ Variabel dependen (Kinerja)

$\mathrm{X}=$ Variabel independen (Pengawasan)

$\mathrm{a}=$ Konstanta (nilai $\mathrm{Y}$ apabila $\mathrm{X}=0$ )

$\beta=$ Koefisien regresi (nilai peningkatan ataupun penurunan)

Berdasarkan persamaan di atas dapat dijelaskan bahwa :

1) Nilai Konstanta $=\mathbf{4 , 5 4 5}$. Berarti saat Pengawasan dianggap nol (diabaikan) maka Disiplin Kerja Guru sebesar 4,545 satuan.

2) Koefisien variabel Pengawasan 0,371. Berarti jika Pengawasan dinaikkan 1 satuan, maka Disiplin Kerja Guru Guru SMK "XY" Pekanbaru naik sebesar 0,371 satuan. Koefisien variabel Pengawasan bertanda positif. Berarti semakin besar nilai Pengawasan yang ada maka Disiplin Kerja Guru SMK "XY" Pekanbaru akan meningkat.

\section{Uji t (Parsial)}

Uji ini digunakan untuk mengetahui tingkat signifikan pengaruh variabel bebas (Pengawasan) terhadap variabel terikat (kinerja).

Nilai $\mathrm{t}$ hitung sebagaimana hasil olah dengan SPSS pada tabel 6 di atas sebesar 5,790 $>$ nilai $\mathrm{t}_{\text {tabel }}(2,021)$ maka Ho ditolak dan $\mathrm{Ha}$ diterima artinya ada pengaruh variable Pengawasan terhadap Disiplin Kerja Guru. 
Nilai signifikansi diperoleh $0,000<0,05$ bermakna pengaruh variable Pengawasan terhadap kinerja adalah signifikan. Jadi dapat diputuskan bahwa Pengawasan berpengaruh positif dan signifikan terhadap Disiplin Kerja Guru .

Untuk mengetahui besarnya pengaruh Pengawasan terhadap Disiplin Kerja Guru SMK "XY" Pekanbaru dilakukan dengan mencari koefisien determinasi $\left(\mathrm{R}^{2}\right)$. Setelah dilakukan pengolahan data maka diperoleh nilai $\mathrm{R}^{2}$ sebagaimana dapat dilihat pada tabel 5.37 berikut ini :

\section{Tabel 7 Hasil Pengujian R-square (Koefisien Determinan)}

\begin{tabular}{|l|c|r|r|r|}
\hline Model & \multicolumn{1}{|c|}{$\mathrm{R}$} & $\mathrm{R}$ Square & $\begin{array}{c}\text { Adjusted R } \\
\text { Square }\end{array}$ & $\begin{array}{c}\text { Std. Error of the } \\
\text { Estimate }\end{array}$ \\
\hline 1 & $.675^{\mathrm{a}}$ & .456 & .442 & 4.55369 \\
\hline
\end{tabular}

a. Predictors: (Constant), Pengawasan

b. Dependent Variable: Disiplin Kerja

Dari tabel 7 diperoleh nilai r-square (koefisien determinasi) sebesar 0,456 atau 45,6\%. Hal ini menjelaskan bahwa faktor Pengawasan memberikan sumbangan pengaruh terhadap Disiplin Kerja Guru SMK "XY" Pekanbaru sebesar 45,6\% sedangkan sisanya sebesar $(100 \%-45,6 \%)=54,4 \%$ dipengaruhi oleh variabel lain diluar variabel dalam penelitian ini

\section{Simpulan}

Simpulan hasil penelitian ini dapat Penulis papar sebagai berikut :

a. Nilai Konstanta $=\mathbf{4 , 5 4 5}$, berarti saat Pengawasan dianggap nol (diabaikan) maka Disiplin Kerja Guru sebesar 4,545 satuan. Sementara nilai koefisien variabel Pengawasan adalah 0,371. Berarti jika Pengawasan dinaikkan 1 satuan, maka Disiplin Kerja Guru SMK "XY" Pekanbaru naik sebesar 0,371 satuan. Koefisien variabel Pengawasan bertanda positif. Berarti semakin besar nilai Pengawasan yang ada maka Disiplin Kerja Guru SMKM 3 Terpadu Pekanbaru akan meningkat.

b. Nilai t_hitung Variabel Pengawasan $>t_{\text {_tabel }}$ $(5,790>2,021)$ maka Ho ditolak dan $\mathrm{Ha}$ diterima artinya ada pengaruh variable Pengawasan terhadap Disiplin Kerja Guru.

Eko dan Bisnis (Riau Economics and Business Reviewe) Volume 10, Nomor 3, 27 September 2019
Nilai signifikansi diperoleh $0,000<0,05$ bermakna pengaruh variable Pengawasan terhadap kinerja adalah signifikan. Maka dinyatakan bahwa variabel Pengawasan berpengaruh positif dan signifikan terhadap Disiplin Kerja Guru.

c. Nilai diperoleh r-square (koefisien determinasi) sebesar 0,456 atau $45,6 \%$. Hal ini menjelaskan bahwa faktor Pengawasan memberikan sumbangan pengaruh terhadap Disiplin Kerja Guru SMK "XY" Pekanbaru sebesar 45,6\% sedangkan sisanya sebesar $(100 \%-45,6 \%)$ $=54,4 \%$ dipengaruhi oleh variabel lain diluar variabel dalam penelitian ini.

\section{DAFTAR RUJUKAN}

Ardiana, Titin Eka, dkk, 2018, Pengaruh Persepsi Guru Atas Gaya Kepemimpinan Situasional Kepala Sekolah Terhadap Kinerja Guru Akuntansi SMK Di Kota Madiun, Prosiding Seminar Nasional da Call for Paper ke-3 Universitas Muhammadiyah Panorogo

Fitrianingrum , Eva Dila, 2015, Pengaruh Pengawasan Terhadap Disiplin Kerja Pada kantor Kecamatan Samarinda Ulu Kota Samarinda, eJournal Administrasi Negara,3(5), Universitas Mulawarman, Samarinda

Handoko, 2012. Manajemen Personalia dan Sumber Daya Manusia. (Edisi Kedua. Cetakan XVIII). Yogyakarta: BPFE.

Hasibuan, Malayu SP, 2017. Manajemen Sumber Daya Manusia. (Cetakan Kedua Puluh Satu) Jakarta: PT. Bumi Aksara.

Kadarisman, M, 2014, Manajemen Pengembangan Sumber Daya Manusia, Rajawali, Jakarta

Mangkunegara, Anwar Prabu, 2011. Memahami Profesi dan Disiplin Kerja Guru. Jakarta: The Minang Foundation

Muhalli, 2018, Arah Pengembangan Pendidikan Masa Kini Menurut Perspektif Revolusi Industri 4.0, Seminar Nasional Lembaga Penelitian dan Pendidikan (LPP) Mandala, Universitas Muhammadiyah Mataram 
Mulyadi, 2016, Sistem Akuntansi, Edisi 4, Salemba Empat, Jakarta

Nellitawati, 2012, Kontribusi Pengawasan Kepala Sekolah Terhadap Disiplin Kerja Guru SMA Negeri Di Kecamatan Koto Tangah Padang, Pedagogi ; Jurnal Ilmu Pendidikan, Universitas Negeri Padang

Purba, Febriana Louise, 2011, Pengaruh Pengawasan Terhadap Disiplin Kerja Karyawan Pada PT. Bank Perkreditan Rakyat Pijer Podi Kekelengen Desa Sukamakmur Kecamatan Sibolangit, Repositori Institusi Universitas Sumatera Utara.

Rafiie, Said Achmad Kabiru, 2017, Manajemen Teori dan Aplikasi, Alfabeta, Jakarta.

Siagian, Sondang P, 2010. Manajemen Sumber Daya Manusia, Bumi Aksara, Jakarta

Sinambela, Lijan Poltak , 2016, Manajemen Sumber Daya Manusia, Cet. Pertama, Bumi Aksara, Jakarta

Sugiyono, 2014. Metodologi Penelitian Bisnis, Cetakakan ke-18, Alfabeta, Bandung

Sutrisno, Edi, 2017, Manajemen Sumber Daya Manusia, Cetakan ke : 9 PT. Kencana, Jakarta

Wardani, Kristi, 2010, Peran Guru Dalam Pendidikan Karakter Menurut Konsep Pendidikan Ki Hadjar Dewantara, Proceedings of The 4th International Conference on Teacher Education; Join Conference UPI \& UPSI Bandung.

Yapentra, Arhipen, 2018, Analisis Implemen-tasi Sanksi Pada Rumah Makan Padang (Unit Usaha Dengan Konsep manajemen syariah, Jebi (Jurnal Ekonomi Dan Bisnis Islam)-Volume 3, Nomor 1, UIN Imam Boniol Padang 